Commentary

\title{
Entrepreneurship and Innovation in the Fight Against Human Trafficking
}

\author{
Christina Bain \\ Initiative on Human Trafficking and Modern Slavery, Babson College, Wellesley, MA 02457, USA; E-Mail: cbain@babson.edu
}

Submitted: 23 February 2017 | Accepted: 8 May 2017 | Published: 23 June 2017

\begin{abstract}
There has been much discussed and written on the benefits of entrepreneurship education, as well as the importance of early access to this type of learning. But how can entrepreneurship education train and inspire the next generation of antitrafficking leaders? How can entrepreneurship also be a driver for prevention and a source of economic stability for those at-risk and survivors of human trafficking? At present, there are entrepreneurs and entrepreneurs-in-training at multiple age levels coming from a variety of backgrounds, incomes, and circumstances who will develop groundbreaking strategies and solutions in the fight against trafficking. These current and future entrepreneurs can also provide fresh perspectives to those in government and business while building more effective tri-sector coalitions and partnerships that address human trafficking. This article explores how and why entrepreneurship can be a key vehicle for social change and innovations in combating human trafficking, along with providing a multi-ingredient recipe of prosperity for those most vulnerable.
\end{abstract}

\section{Keywords}

business; education; entrepreneurship; human trafficking; secondary education; youth

\section{Issue}

This commentary is part of the issue "Perspectives on Human Trafficking and Modern Forms of Slavery", edited by Siddharth Kara (Harvard Kennedy School, USA).

(C) 2017 by the author; licensee Cogitatio (Lisbon, Portugal). This article is licensed under a Creative Commons Attribution 4.0 International License (CC BY).

\section{Introduction}

As stakeholders look to new and innovative solutions in the fight against human trafficking, the crucial role of the private sector has been recognized. With this recognition, training a new generation of business leaders in antitrafficking strategies has become even more critical as one significant component to address this very complex issue. Entrepreneurship education in business school curricula, for youth and within other programming, can also play a meaningful role in tackling human trafficking as a means of prevention to those at-risk to trafficking; survivors of human trafficking; and a new wave of entrepreneurs who are blazing a trail in anti-trafficking innovations. While the concept of entrepreneurship education within the anti-trafficking space has yet to generate research and wide-spread evaluation as to its overall impact, it deserves attention as an emerging strategy to confront a multi-faceted global challenge.

The global scope of human trafficking is widely debated, and different data sets exist within the anti- trafficking field. The International Labour Organization estimates that close to 21 million men, women, and children are held in conditions of forced labor (International Labour Organization, 2012). These adults and children are trapped in unimaginable conditions and forced to endure extreme torture and deprivation. The majority of these victims are enslaved in various sectors, such as construction, manufacturing, and seafood processing (International Labour Organization, 2012). The International Labour Organization further estimates that out of the 21 million suffering, $68 \%$ are victims of labor exploitation and $22 \%$ are victims of sexual exploitation (International Labour Organization, 2012). Therefore, it is vital to engage the business community in this global fight.

Human traffickers are in the business of making profits and large profits in the billions annually (International Labour Organization, 2014). Human trafficking is just one part of a lucrative global illicit economy. Therefore, the importance of fighting the global crime of human trafficking with the legitimate economy is imperative (Shelley \& Bain, 2015). In the past decade, different initiatives have 
emerged in order to engage, assist, and convene those in the private sector to look more deeply into how business and business leaders can make a significant impact in the anti-trafficking movement. From the travel and tourism industry launching critical campaigns against sex trafficking to the financial sector utilizing data analysis tools to track the financial transactions of traffickers, the private sector has begun to make headway (Bain, Metallidis, \& Shelley, 2014). Anti-trafficking public policy addressing the private sector has developed through laws like the California Transparency in Supply Chains Act of 2010 (United States Department of Labor, n.d.) and the UK Modern Slavery Act of 2015 (Modern Slavery Act, 2015). Since the importance of business has been identified, it is even more essential to train the next generation of business leaders and entrepreneurs how to think and act critically and effectively around the issue of human trafficking.

In training this next generation of business leaders, entrepreneurship education has been integrated into curricula at business schools globally in addition to traditional corporate management training. Top entrepreneurship programming has developed in schools in the USA, UK, Spain, France, and China (Financial Times, n.d.). Centers, initiatives, research, and core programming now exist and include the Center for Entrepreneurial Studies at Stanford University's Graduate School of Business; the Harvard Business School's Social Enterprise Initiative; Babson College's undergraduate and graduate curricula; and the Entrepreneurship Centre at the University of Oxford's Saïd Business School. In defining entrepreneurship for this next generation of business leaders, the word entrepreneurship has a wide variety of meanings. Definitions often include words like "fulfilling a need" or "opportunity" or "risk-taker." According to John Hagel of Deloitte's Center for the Edge in a recent Harvard Business School Review post, a more effective definition of an entrepreneur might be "someone who sees an opportunity to create value and is willing to take a risk" (Hagel, 2016). Entrepreneurs see a world of endless possibility and the possibility for dynamic and systemic change for the world's most pressing challenges. Entrepreneurs use "creative and innovative approaches to create value for stakeholders and society" (Neck, n.d.). Entrepreneurs, through their educational training, also have an understanding of business and business models to advance their global work and outlook.

Early entrepreneurship education at the primary (elementary education) and secondary school (high school or final years of statutory education) levels also creates a path to future changemakers. It has been noted that teaching business skills and entrepreneurship at an early age builds confidence, leadership, critical thinking, financial literacy, communication skills, and most importantly, encourages a passion for a cause and/or social change. This type of "learning opens a child's world to something greater than themselves," and by learning these basic skills at an early age, colleges and universities can then further develop the abilities of these students with their own entrepreneurship curricula (Studdard, Dawson, \& Jackson, 2013). Early entrepreneurship education can also provide a path to success for women and underrepresented groups, and programs like the Network for Teaching Entrepreneurship (NFTE) provide programming for low-income and at-risk students (Studdard et al., 2013).

If today's entrepreneurs-in-training begin to think analytically around issues like human trafficking, groundbreaking approaches have the ability to materialize and grow. Entrepreneurship education has the dual capacity to create the next leaders of the anti-trafficking movement and/or can also hold the key to lasting economic stability for those who are survivor leaders and at-risk for this horrific crime.

\section{Human Trafficking, Education, and Entrepreneurship: The New Wave of Changemakers}

Entrepreneurship education and entrepreneurs focused on addressing human trafficking are emerging globally. In recent years, entrepreneurs have developed a number of start-ups, nonprofits, and ventures to tackle this egregious human rights abuse. Many of these entrepreneurs are working on a tri-sector level: engaging governments, the private sector, and civil society as a coalition for good. Entrepreneurs are coming from a diversity of backgrounds such as business, government, technology, the arts, and academia. Founders are also of all ages. Importantly, survivors of human trafficking have become entrepreneurs ensuring that they are never at-risk for trafficking again.

One example of incorporating anti-trafficking strategy into entrepreneurship education is the Human Freedom Entrepreneurial Leadership Program within Babson College's Initiative on Human Trafficking and Modern Slavery. Started in 2016, this new program teaches secondary school (high school) students a curriculum of basic human trafficking awareness, statistics, cases, supply chains, and the role of business and entrepreneurship in the fight against trafficking. The curriculum is taught within a broader after-school entrepreneurship program in multiple schools (public, private, parochial, international, and charter) in the Boston, Massachusetts, USA metro area. Students have the option of crafting entrepreneurial endeavors to tackle human trafficking whether as a single start-up or as a separate business that will seek to combat human trafficking within its supply chains. Students then compete in a pitch competition for the Davis Spencer Freedom Innovation Award which includes seed money for the most researched, unique, and developed entrepreneurial endeavor (Sweeny, 2016). The spring 2016 winning team, two students from Fontbonne Academy in Milton, Massachusetts, USA, created the nonprofit, Guardian, to educate pre-teen girls on Internet safety as a means of sex trafficking prevention. The students developed an extensively researched 
plan to include public and private sector partners to further develop their curriculum and programming. The students hope to launch their program in gateway cities (economically challenged Massachusetts urban centers with untapped potential) in Eastern Massachusetts, USA.

Entrepreneurs from a variety of backgrounds and ages are impacting the anti-trafficking movement across the globe. Her Future Coalition (formerly Made By Survivors), a social enterprise based in the USA, has made groundbreaking changes with their global work that began in 2005 (Bhardwaj \& Goldberg, 2014). The founders, mobilized to action after learning about the horrors of sex trafficking in Nepal and India, developed a business model to ensure that trafficking survivors were economically empowered as entrepreneurs themselves and not at-risk for trafficking again. Made By Survivors worked with other suppliers and partners to sell products made by these survivor-entrepreneurs to those in the USA and beyond. Now, Her Future Coalition is working to expand shelter services for survivors and those at-risk, as well as education and lasting employment.

Other entrepreneurs are tackling global supply chains, technology, and the business sector itself. Remake, a California-based social enterprise, utilizes a platform to foster humanity within fashion markets. Through this "storytelling platform," Remake seeks to build a social and consumer movement around stopping human trafficking within fashion supply chains (Binkowski, n.d.). The Mekong Club, an organization based in Hong Kong, developed to specifically support and assist the private sector in the fight against human trafficking in Asia. The Mekong Club has crafted specific networking groups to work toward common goals and collaboration, while offering business expertise in supply chains and operations (Miquiabas, 2015). Marinus Analytics, founded by a graduate of Carnegie Mellon University, developed a software tool to mine the Internet to detect data on human trafficking operations (Gannon, 2015). This software tool, Traffic Jam, began as a senior honors thesis which later led to further research and data analytics in the fight against trafficking. Marinus takes a multistakeholder approach to anti-trafficking strategy, working with the NGO community, private sector, government, law enforcement, and academia to combat this crime. Due to Traffic Jam, 120 victims of trafficking have been rescued in the USA, and the tool is now employed by 75 law enforcement agencies (Tartan Board, 2015).

Other organizations have launched initiatives to support entrepreneurship. The Organization for Security and Co-operation in Europe (OSCE) has launched a project to support local anti-trafficking efforts, including economic opportunities for survivors of human trafficking in the Ukraine (OSCE, 2015). This project is an example of a joint government/civil society partnership toward a common cause. This project, also funded by the Canadian and Norwegian governments, gives NGOs the opportunity to conceive new social enterprises that train and employ survivors of human trafficking, enterprises such as a greenhouse business, a canteen, and a workshop (OSCE, 2015).

\section{Conclusion}

As global crime and the illicit economy continue to evolve, it is vital that key stakeholders look at fresh and innovative thinking to solve these complex challenges. Entrepreneurs and survivor-entrepreneurs can play a significant role in blazing a trail of change across the antitrafficking movement and confronting the issue of human trafficking from a variety of angles. Business schools globally have an opportunity to make a meaningful dent in human trafficking by encouraging coursework on the topic including looking at it through a corporate and entrepreneurial lens. Educators and programming at the primary and secondary school levels also can be at the forefront of global change in this area. By training earlier and earlier, youth entrepreneurs can be on a direct path by the time they reach university level and well on their way towards success and change in the anti-trafficking field.

The role of business must also continue to be highlighted in anti-trafficking discourse and public policy discussions, as well as initiatives to engage more and more sectors in this global fight. Corporations, governments, and civil society are working together in a number of antitrafficking initiatives. Entrepreneurs have the gifts to be the conveners, the connectors, and the changemakers who will work on a tri-sector level and work alongside corporations, governments, and within civil society to assist in innovative approaches and tactics. Traffickers have created their own business models, and now it is time for the anti-trafficking movement to push further ahead in innovation to force true systemic transformation.

\section{Conflict of Interests}

The author declares no conflict of interests.

\section{References}

Bain, C., Metallidis, E.M., \& Shelley, L. (2014). Hedging risk by combating human trafficking: Insights from the private sector. Geneva: World Economic Forum.

Bhardwaj, G., \& Goldberg, E.S. (2014). Made by survivors: Business solution for a social problem (Babson College No: BAB271C). Wellesley, MA: Babson College.

Binkowski, K. (n.d.). Together, we can remake our world: Ayesha barenblat, founder of remake. The Good Trade. Retrieved from http://www.thegoodtrade. com/features/interview-series-ayesha-barenblat-fou nder-of-remake

Financial Times. (n.d.). Business education: Top mbas for entrepreneurship 2016. FT.COM. Retrieved from http://rankings.ft.com/businessschoolrankings/topmba-for-entrepreneurship-2016

Gannon, J. (2015). Software developed by CMU student helps find online sex traffickers. Pittsburgh Post- 
Gazette. Retrieved from http://www.post-gazette. com/local/city/2015/08/28/Software-developed-byCMU-student-helps-find-online-sex-traffickers/stori es/201508280284

Hagel, J. (2016). We need to expand our definition of entrepreneurship. Harvard Business Review. Retrieved from https://hbr.org/2016/09/we-need-toexpand-our-definition-of-entrepreneurship

International Labour Organization. (2012). Global estimate on forced labour. Geneva: ILO. Retrieved from http://www.ilo.org/wcmsp5/groups/public/@ed_no rm/@declaration/documents/publication/wcms_18 1953.pdf

International Labour Organization. (2014). Profits and poverty: The economics of forced labour. Geneva: ILO. Retrieved from http://www.ilo.org/wcmsp5/groups/ public/---ed_norm/---declaration/documents/public ation/wcms_243391.pdf

Miquiabas, B. (2015). How a hong kong not-for-profit is helping the private sector fight human trafficking. Forbes. Retrieved from http://www.forbes.com/ sites/bongmiquiabas/2015/05/26/how-a-hong-kong -not-for-profit-is-helping-the-private-sector-fight-hu man-trafficking/\#6b55e64552db

Modern Slavery Act. (2015). Sec. 54 Transparency in supply chains, etc. Retrieved from http://www.legis lation.gov.uk/ukpga/2015/30/section/54/enacted

Neck, H. (n.d.). Learning to think like an entrepreneurial leader. Babson College. Retrieved from http://www. babson.edu/executive-education/thought-leadersh
ip/education/Pages/learning-to-think-like-an-entre preneurial-leader.aspx

Organization for Security and Co-operation in Europe. (2015). OSCE promotes social entrepreneurship to prevent human trafficking in Ukraine. OSCE. Retrieved from http://www.osce.org/ukraine/173816

Shelley, L., \& Bain, C. (2015). Human trafficking: Fighting the illicit economy with the legitimate economy. Social Inclusion, 3(1), 140-144.

Studdard, N. L., Dawson, M., \& Jackson, N. L. (2013). Fostering entrepreneurship and building entrepreneurial self-efficacy in primary and secondary education. Creative Knowledge Society, 3(2), 1-14.

Sweeny, S. (2016). Babson to hold first annual multischool business plan competition for human freedom entrepreneurial leadership program. Babson Blogs. Retrieved from http://blogs.babson.edu/ news/2016/05/11/babson-to-hold-first-annual-multi -school-business-plan-competition-for-human-free dom-entrepreneurial-leadership-program

Tartan Board. (2015). Alumna's startup shows how to benefit from CMU. The Tartan. Retrieved from https://thetartan.org/2015/9/14/forum/emilyk

United States Department of Labor. (n.d.). California Transparency in Supply Chains Act. Bureau of International Labor Affairs, United States Department of Labor. Retrieved from https://www.dol.gov/ilab/childforced-labor/California-Transparency-in-Supply-Chai ns-Act.htm

\section{About the Author}

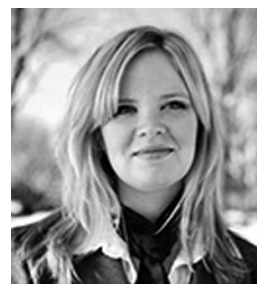

Christina Bain is the Director of Babson College's Initiative on Human Trafficking and Modern Slavery where she is focused on the role of business, entrepreneurial solutions, and training the next generation of business leaders in combating human trafficking. Christina has served on the World Economic Forum's Partnering Against Corruption Initiative (PACI); Meta-Council on the Illicit Economy; the Global Agenda Council on Human Rights; and as co-Vice Chair of the Global Agenda Council on Illicit Trade and Organized Crime. 